\title{
ARTICLES
}

Submitted 02.02.2017. Approved 11.17.2017

Evaluated through a double-blind review process. Scientific Editor: Arthur Ridolfo Neto

Original version

DOI: http://dx.doi.org/10.1590/So034-759020180407

\section{ANTECEDENTS AND CONSEQUENCES OF CORPORATE IMAGE: CONVENTIONAL AND ISLAMIC BANKS}

\author{
Antecedentes e consequências da imagem corporativa: Bancos convencionais e \\ islâmicos
}

\author{
Antecedentes y consecuencias de la imagen corporativa: Bancos \\ convencionales e islámicos
}

\begin{abstract}
Islamic and conventional banks differ in basic philosophy and objectives although both perform the same service. This study used cognitive, affective, and conative sequence to examine antecedents and consequences of corporate image of conventional and Islamic banks in Pakistan. Self-administered questionnaires collected empirical data from 320 respondents. It was found that non-firm communication and corporate social responsibility significantly relate to brand familiarity and corporate image in case of Islamic banks. Brand familiarity significantly builds corporate image, which confirms the cognitive, affective, and conative sequence. Corporate image creates positive brand attitude and intention to use banking services. In case of conventional banks, only firm communication significantly relates to corporate image and brand familiarity. The relationship of corporate image with brand attitude and intention to use the service are similar to Islamic banks. This study can help banks to invest in building respective antecedents which can increase intention to use their services.

KEYWORDS | Corporate image, Islamic banks, conventional banks, intention to use, mediation.
\end{abstract}

\section{RESUMO}

Bancos islâmicos e convencionais diferem em termos de filosofia e objetivos básicos, embora ambos desempenhem o mesmo serviço. Este estudo utilizou a sequência cognitiva, afetiva e conativa para examinar os antecedentes e consequências da imagem corporativa de bancos convencionais e islâmicos no Paquistão. $A$ partir do uso de questionários auto-aplicados, foram coletaram dados empíricos de 320 entrevistados. Verificou-se que no caso de bancos islâmicos a comunicação não relacionada à firma e a responsabilidade social corporativa estão significativamente relacionadas à familiaridade com a marca e imagem corporativa. A familiaridade da marca tem participação significativa na criação da imagem corporativa, o que confirma a sequência cognitiva, afetiva e conativa. A imagem corporativa é responsável pela criação de uma atitude positiva em relação à marca e pela intenção de usar serviços bancários. No caso dos bancos convencionais, somente a comunicação da firma está relacionada de forma significativa à imagem corporativa e à familiaridade da marca. A relação da imagem corporativa com atitude da marca e intenção de uso do serviço é semelhante para os bancos islâmicos. Este estudo pode ajudar os bancos a investirem no desenvolvimento de seus respectivos antecedentes, o que pode aumentar a intenção de uso de seus serviços.

PALAVRAS-CHAVE / Imagem corporativa, bancos islâmicos, bancos convencionais, intenção de uso, mediação.

\section{RESUMEN}

Los bancos islámicos y convencionales difieren en su filosofía básica y objetivos, aunque ambos realizan el mismo servicio. Este estudio usó la secuencia cognitiva, afectiva y conativa para analizar antecedentes y consecuencias de la imagen corporativa de bancos convencionales e islámicos en Paquistán. Los cuestionarios autoadministrados colectaron datos empíricos de 320 entrevistados. Se encontró que la comunicación no corporativa y la responsabilidad social corporativa se relacionan significativamente con la familiaridad de la marca y con la imagen corporativa en el caso de los bancos islámicos. La familiaridad de la marca construye significativamente la imagen corporativa, que confirma la secuencia cognitiva, afectiva y conativa. La imagen corporativa crea actitud e intención positivas para usar servicios bancarios. En el caso de bancos convencionales, solamente la comunicación corporativa se relaciona significativamente con la imagen corporativa y la familiaridad de la marca. La relación de la imagen corporativa con la actitud y la intención de la marca de usar el servicio son semejantes a las de bancos islámicos. Este estudio puede ayudar a los bancos a invertir en cons. truir sus respectivos antecedentes que pueden aumentar la intención de usar sus servicios.

PALABRAS CLAVE / Imagen corporativa, bancos islámicos, bancos convencionales, intención de uso, mediación. 


\section{INTRODUCTION}

Islamic banking is being acknowledged as a rapidly growing service industry, not only in Muslim but even in non-Muslim countries (Dusuki \& Abdullah, 2007). Globally, over 300 Islamic banks and other financial institutions exist in 48 countries that are managing funds of around $\$ 300$ billion, with deposits exceeding $\$ 120$ billion (Memon, 2007). Wherever Islamic banks exist alongside conventional banks, it becomes very important to attract and retain customers who are inclined to opt for socially responsible banking services that adhere to Islamic rules. This includes a vision of a just and fair society, as well as brotherhood and cooperation that is in compliance with the Shariah (Iqbal \& Molyneux, 2005). While the literature on customer satisfaction and service quality in the banking sector is in abundance, the importance of bank's image as strong influencing a customer's buying behavior has been asserted by Erol, Kaynak, and El-Bdour (1990). Other influences on the selection of banks include religious motivation, economic influences, friends and family (Metawa \& Almossawi, 1998). These are more evident in Muslim countries, such as Jordan. Thus, the argument arises that Islamic version of financial products and services no longer remain the exclusive selection criteria to use a specific type of bank. In Malaysia, for example, marketing strategies, including the availability of fast and quality service are emerging as a pertinent selection technique by customers (Dusuki \& Abdullah, 2007). In the field of marketing and management, emphasis is on corporate image to acquire and sustain the patronage of customers of Islamic banks (Kaurav, Paul, \& Chowdhary, 2015; Richardson \& Robinson, 1986).

Pakistan's banking sector continues to grow despite increasing inflation, energy crisis, and security concerns, and it is attracting the interest of academics, researchers, and policymakers alike (Iqbal \& Molyneux, 2005). The banking sector of Pakistan underwent major structural changes towards beginning of the millennium, leading to privatization, rapid entry and growth of foreign and Islamic banks, introduction of human resource management systems and diversification of financial institutions and markets (Obaid, 2013). While the establishment of Islamic banking system of Pakistan has its roots in the early 1980s, it was relaunched in 2001 when Meezan Bank became the first certified Islamic bank of the country. By 2007, six fullfledged Islamic banks were operational (Khattak \& Rehman, 2010). The central State Bank of Pakistan has made Islamic banking a priority focus, and introduced a comprehensive legal, regulatory, and Shariah compliance framework for its development (Islamic Banking Bulletin, 2016).
Recently, Pakistani Islamic banking industry has been included in the nine core markets of international participation banking industry. Other markets include Bahrain, Qatar, Indonesia, Saudi Arabia, Malaysia, United Arab Emirates, Turkey, and Kuwait (World Islamic Banking Competitiveness Report, 2016). Within Pakistan, Islamic banking system holds over 11.4 percent share in assets and 13.2 percent share in deposits of the country's overall banking system (Islamic Banking Bulletin, 2016). It has over 1200 branches in over 80 districts across Pakistan and has maintained a growth momentum along with an increasing base. By 2018 , this is expected to have risen to 2000 branches with a market share of 15 percent (State Bank of Pakistan, 2014). This continued expansion of the rise in Islamic banking is evidence of its growing acceptability among customers. Similar to the global trend, Pakistani Islamic banks are also striving hard to acquire maximum market share, using established strategies offering a portfolio of products and services, focusing on quality of service, offering internet-based services, and building company image in the customers' minds (Ahmad, Rehman, Saif, \& Safwan, 2010; Haron, Ahmad, \& Planisek, 1994; Mokhtar, Abdullah, \& Alhabshi, 2008; Raza \& Hanif, 2013). Moreover, it is suggested that Islamic banks may be prone to avoiding issues that negatively affect their corporate image (Maali, Casson, \& Napier, 2006).

The Islamic banking industry holds a reasonable share in the world financial sector and is identified as a dynamic segment of the global banking industry, in which traditional marketing rules may not apply in their entirety (Amin, Isa, \& Fontaine, 2013). Therefore, we intend to explore the antecedents and consequences of corporate image by conducting a comparison of conventional banks and its rival in the financial market, that is Islamic banks of Pakistan. Hence, we build the following objectives for this study:

1. to understand the influence of antecedents of corporate image on its consequences, such as brand attitude and intention to use behavior in the banking industry and conduct a comparison of conventional and Islamic banking;

2. to examine the mediating role of corporate image between antecedents and consequences of Corporate Image $(\mathrm{Cl})$ and compare the influences with respect to different banking systems and

3. to investigate the building influences of those antecedents which are at the discretion of management on those which are not at the disposal of management and discuss the implications of these results. 
The rest of this paper presents a critical review of the existing literature and builds a conceptual framework, from which hypotheses are formulated. In order to test the hypotheses proposed in the study, a quantitative survey is adopted and statistical software are used for data analysis. After discussing the salient findings of the study, we address the limitations and future research directions. Finally, a brief conclusion is provided at the end of the paper.

\section{LITERATURE REVIEW}

\section{Corporate brand image}

Traditionally, corporate image was seen as a concern of the public relations department. However, the concept has evolved and is recognized as a critical asset for competitive advantage. Eventually, contemporary research asserts the need to reactively, if not proactively, manage corporate image (Gray \& Balmer, 1998). It has also been identified as the mental image of the tangible and intangible elements of business held by a segment of the public or audience. Through corporate communications, an intended image is first created and then concentrated efforts are exerted on managing this mental picture (Balmer \& Greyser, 2003; Gray \& Balmer, 1998; Johnson \& Zinkhan, 1990).

Regardless of the contestation over the different definitions of corporate image, for the sake of this paper, we contend that the corporate image is the belief of the organization's members of the existing (Dutton, Dukerich, \& Harquail, 1994) or future (Whetten, Lewis, \& Mischel, 1992) perception of its external stakeholders. In marketing, strong relations have been established between corporate image and perceived customer satisfaction (Hart \& Rosenberger, 2004) to the extent that engineering the customer experiences in favor of a corporate image have been suggested (Carbone \& Haeckel, 1994; Shee \& Abratt, 1989).

In the banking sector, corporate image is the most effective tool for differentiations and the main management tool for banks and is considered most relevant nowadays (Van Riel, Lemmink, \& Ouwersloot, 2001; Worcester, 2009). Corporate social responsibility is an important factor determining the bank's image which was ignored earlier (Castelo \& Lima, 2006; Souiden, Kassin, \& Hong, 2006). In a study Kim (2006) argued that corporate ability (product quality, financial performance, and technological innovation) and all perceptions are gathered by corporate image that the stakeholders have about the firm making corporate image a multidimensional image.

Shariah is a set of rules and guidelines described in Islamic Fiqah (jurisprudence) whose major sources are Quran and
Hadiths. Islamic economic system is grounded on the principles of justice, equity, and welfare. Interest is strictly prohibited in Islam and therefore no bank uses interest as pillar of its banking business. Instead, Islam has allowed trade as a source of earnings. Therefore, Islamic banks have to adopt partnership (Musharkah or Mudarbah), rent (Ijarah) or trade (Salam, Murabahah, and Istisana) modes of financing as their source of earnings.

Islamic banks have to follow Shariah principles for their strategic and operational decisions. The State Bank of Pakistan has bound every Islamic bank to constitute a Shariah board which ensures that each business transaction is in line with Shariah principles. Even the transactions which seem doubtful with reference to Shariah transactions is not permissible. As far as credit policies are concerned, Islamic banks cannot finance those businesses which are legal but prohibited in Islamic Shariah, for example cinema and smoking.

Islamic and conventional banks are different in basic philosophy, underlying mechanism and objectives although both perform the same service that is providing solutions to the financing problems of clients. Exhibit 1 describes some major differences.

\section{Antecedents of corporate image}

In the banking sector in particular, a strong corporate image is believed to be a major source of differentiation between conventional and Islamic banks (Osman et al., 2015). It has been suggested that customer satisfaction has a stronger effect on corporate image for non-Muslim customers of banks compared to its Muslim customers (Amin et al., 2013) and that it enhances employee engagement (Hussain, Ishak, Daud, \& Yunus, 2014). Although, the components of corporate image evolve over time, its measurement has included functional and emotional dimensions, related to types and access to the offered services, human resource, security of transactions, trust, corporate social responsibility and other factors (de Leaniz \& Rodríguez, 2016; Hussain et al., 2014; Souiden et al., 2006).

It is not then surprising that much attention has been paid to building a sustainable corporate image through effective financial prospects, corporate communications, and corporate management (Gray \& Balmer, 1998; Van Riel, 1997; Yeo \& Youssef, 2010) through, for example, brand experiences, brand relationships, and brand communities (Abratt \& Kleyn, 2012). In the case of Islamic banks, there is evidence that gaps commonly exist between the communicated and the ideal ethical identities (Haniffa \& Hudaib, 2007). Communicating the corporate image can involve campaigns, non-firm communication (word-of-mouth), internet, and firm communication (advertising, annual reports). 
These are generally considered the domain and expertise of marketing and public relations consultants to build corporate identity cues, visuals, and personalities, thereby increasing brand familiarity (Abratt \& Kleyn, 2012; Balmer \& Greyser, 2006; Darus et al., 2014).

\section{Exhibit 1. Difference between the financial functions of Conventional and Islamic banking system}

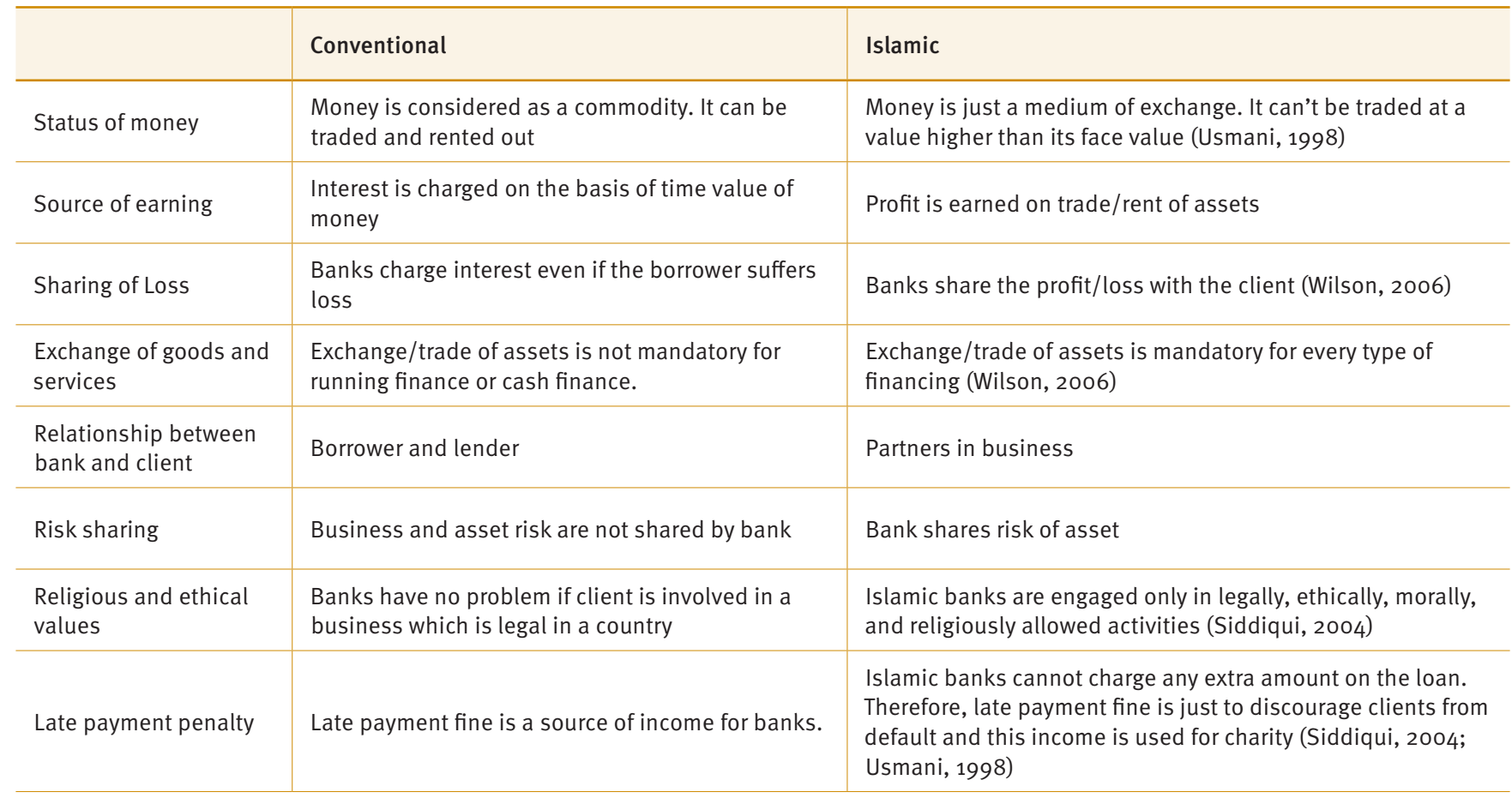

The basic purpose of this paper is to compare the relationship of antecedents and consequences of corporate image of conventional and Islamic banks. We used structural equation model for finding the interdependent relationships of antecedents and consequences of corporate image. Bravo, Montaner, and Pina, (2012) discussed a number of antecedents and consequences of corporate image and built a conceptual model with three dimensions of antecedents' that is firm communication, brand familiarity, and non-firm communication and two dimensions of consequences that is brand attitude and intention to use banking services. In our study we are adding another two dimensions of antecedents that is corporate social responsibility (CSR) and security in the model. In the past, research that compares conventional and Islamic banks has neglected the effect of corporate image on brand attitude and intention to use the specific bank or its products/services.

According to proposed model of Bravo et al. (2012), the corporate image is explained by brand familiarity, firm and nonfirm communication and the resulting image would affect brand attitude directly and intention to use the bank services (ITU) both directly and indirectly. This extended relationship that is discussed by Bravo et al. (2012) is given in Figure 1.

Souiden et al. (2006) hypothesized that greater the brand familiarity, the more favorable is the corporate image, hence it leads to our first hypothesis:

H1: Brand familiarity has a positive relationship with corporate image.

Crane (1990) concluded that corporate advertising in banking services significantly affects the brand awareness, brand familiarity, brand attitude, and indirectly the purchase intention to use the service. The firm communication (advertising and other elements) strengthens the image of the corporation (VillarejoRamos \& Sánchez-Franco, 2005). Therefore, by considering these arguments and previous literature, we hypothesize the following:

H2: Positive firm communication has a positive relationship with corporate image.

H3: Positive firm communication has a positive relationship with brand familiarity.

$\mathrm{H}_{4}$ : Brand familiarity mediates the relationship between firm communication and corporate image. 
Figure 1. Conceptual framework

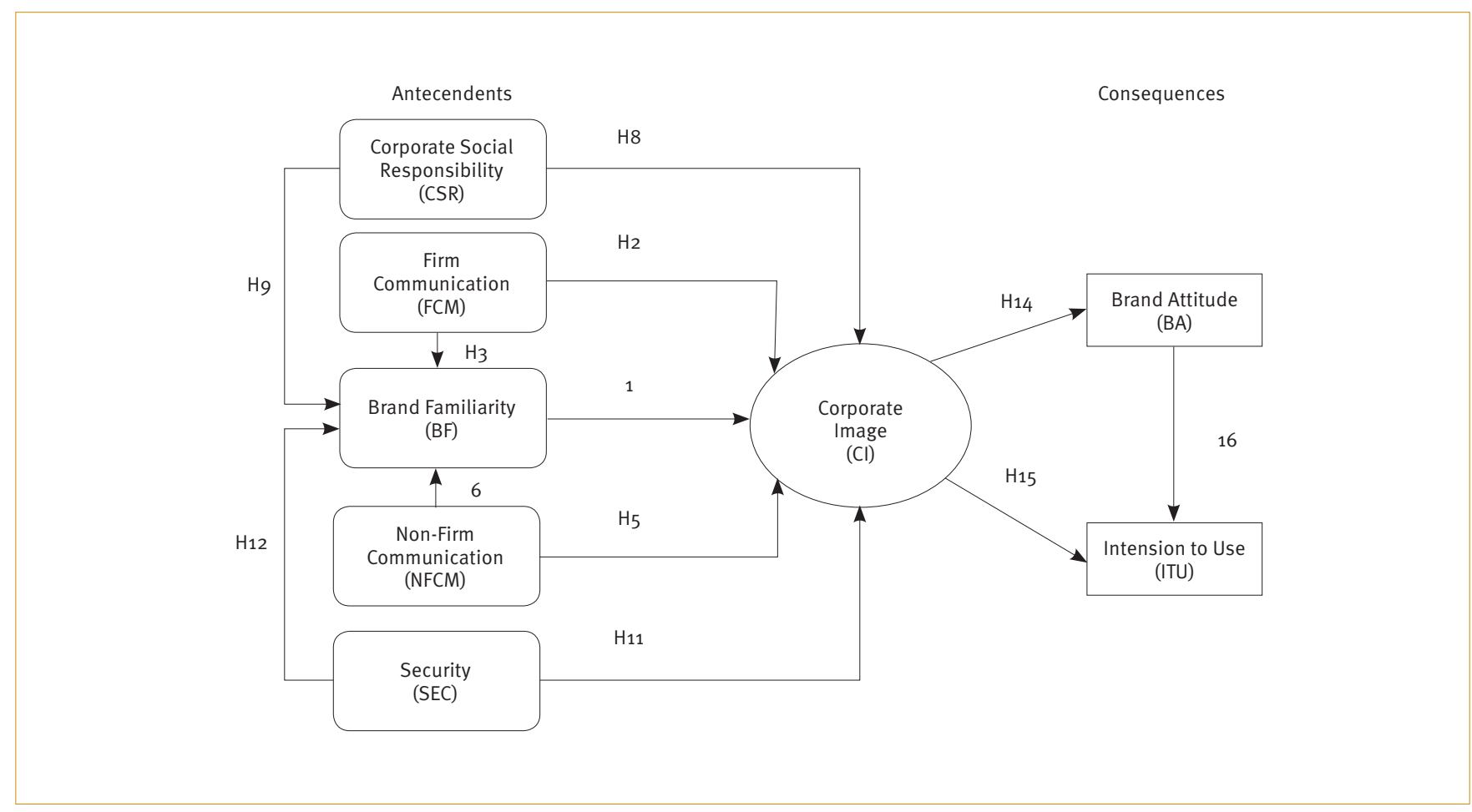

The consumer perceptions of brand are highly influenced by the opinion of friends, family or other people. Gounaris, Stathakopoulos, and Athanassopoulos (2003) show that the non-firm communication world of mouth (WOM) has significant impact on the corporate image. Peer recommendations affect the evaluation, choices or brand familiarity (Gounaris \& Stathakopoulos, 2004). Thus, we advance the following hypotheses:

$\mathrm{H}_{5}$ : Positive non-firm communication has a positive relationship with corporate image.

H6: Positive non-firm communication has a positive relationship with brand familiarity.

H7: Brand familiarity mediates the relationship between non-firm communication and the corporate image.

We extended the Bravo et al. (2012) model by incorporating another two dimensions of antecedents that is corporate social responsibility (CSR) and security in the model. CSR has become useful for differentiating the image of banks and builds brand familiarity in the eyes of customers which ultimately creates a good image for them. CSR is an important factor determining bank image which was ignored earlier (Souiden et al., 2006; Castelo \& Lima, 2006). All religions, in general, emphasize caring and
Islam, in particular, teaches to help and care for needy persons. We believe that CSR activities are positively related with brand familiarity and corporate image. The following hypotheses are advanced.

H8: CSR has a positive relationship with corporate image.

H9: CSR has a positive relationship with brand familiarity.

$\mathrm{H}_{10}$ : Brand familiarity mediates the relationship between CSR and the corporate image.

The second factor that has been added in the model is the security based on the assumption that security may influence the impression of customers for selection of services and building the banks' image. In relation to internet-based services offered by conventional or Islamic banks, security concerns are of prime significance - this is not tangential to other businesses. However, in the case of Islamic banks, the appearance and dress code of human resources can play an additional role in building trust amongst the minds of the customers (Darus et al., 2014; Haniffa \& Hudaib, 2007). Offering secure products and services that comply with Islamic principles is also fundamental in the case of Islamic banks (Amin et al., 2013). Therefore, the adequate provision of security may have a relationship with the brand familiarity and corporate image of the bank. Hence, we hypothesize the following: 
H11: Security has a positive relationship with corporate image.

H12: Security has a positive relationship with corporate familiarity.

$\mathrm{H}_{13}$ : Brand familiarity mediates the relationship between security and the corporate image.

\section{Consequences of corporate image}

Corporate image of banks can affect customer loyalty which is built through trust (Amin et al., 2013). It is seen as a process, in which customers filter the perceptions and experiences of various dimensions of the corporation (Hsiong-Ming, Ching-Chi, \& CouChen, 2011), where a negative evaluation of the bank can lead to a negative attitude towards the corporation and vice-versa. Thus, effective management of corporate image and identity is seen as a prerequisite of favorable attitude (Cornelissen \& Elving, 2003; Ditcher, 1985). Businesses can leverage positive brand attitude through projection of a specific corporate image that builds a related image and personality of the business in the minds of the consumers (Faircloth, Capella, \& Alford, 2001). When customers are clear about the corporate and have developed a positive attitude towards it, uncertainty towards using the products and services offered by the business are lowered and the intention to use is enhanced (Chang \& Liu, 2009).

We adopt the view that the effect of corporate image on the behavior of consumers may be taken in terms of cognitive, affective, and conative sequence (Chiou, Droge, \& Hanvanich, 2002). We believe that the corporate image will give rise to service brand attitude that is global affective response towards the brand and this attitude will be followed by conative response, such as intention to use the service. Chiou et al. (2002) proved that company trust which is influenced by service quality beliefs, positively enhances the behavior intention. This discussion leads to the following hypotheses.

H14: Corporate image has a positive relationship with brand attitude.

H15: Corporate image has a positive relationship with intention to use the banking services.

H16: Brand attitude has a positive relationship with intention to use the banking services.

H17: Brand attitude mediates the relationship between the corporate image and intention to use the banking services.

\section{METHODOLOGY}

\section{Research instrument and data collection}

The use of structured, self-administered questionnaire is popular in eliciting responses from respondents spread over different locations, and these have been used in the examination of brand attitude and intention to use services, as well as for other variables under study (e.g. Bryman \& Bell, 2015; Lafferty \& Goldsmith, 2005; Ruth \& Simonin, 2003; Saunders, Lewis, \& Thornhill, 2015).

In the same line, primary data for this study was collected through self-administered questionnaire. 400 customers were selected (200 each in conventional and Islamic banks) from four cities of Pakistan, including Multan, Lahore, Karachi, and Islamabad (100 from each city from different branches). This data collection was made during May-September 2016. Using systematic sampling technique, customers of banks were sent printed copies of the questionnaire in pre-paid return envelopes. These questionnaires were filled out by bank customers of different professional backgrounds, for example jobholders, businessmen, and others.

Systematic sampling technique was used such that every 6th customer who visited a specific branch of a specific type of bank (Islamic or conventional) was contacted for the study. 320 usable questionnaires were returned with 80 percent response rate.

The data profile of these respondents is as follows: 62 percent, 23 percent, and 15 percent of the respondents belong to age groups 20-40, 40-50, and above 50 years respectively. 66 percent respondents are males. 71 percent respondents are jobholders and 29 percent are businessmen. 56 percent, 28 percent, and 16 percent of the sample consist of those with undergraduate, graduate, and informal education respectively.

The questionnaire included measures of all the variables which have been discussed above in the literature. Exhibit 2 shows the adapted scales and respective sources. It consists of Likert-type scale for corporate social responsibility, firm communication, brand familiarity, non-firm communication, security, corporate image, brand attitude, and intention to use the banking services. The Likert-type items were anchored at $1=$ strongly disagree; $2=$ disagree; $3=$ somewhat disagree; $4=$ neutral; $5=$ somewhat agree; $6=$ agree; and $7=$ strongly agree. In addition to the items for variables, questions were also asked regarding demographics, such as age group, gender, location, bank type, and profession. The survey instrument was pre-tested to ensure its clarity and comprehensibility to the respondents. 


\section{Exhibit 2. Sources of scales for variables in the survey instrument}

\begin{tabular}{l|l}
\hline Variable & Scale \\
\hline $\begin{array}{l}\text { 1. Corporate Social } \\
\text { Responsibility }\end{array}$ & $\begin{array}{l}\text { Adapted from Lichtenstein, Drumwright, and } \\
\text { Braig (2004) }\end{array}$ \\
\hline 3. Brand Familiarity & Adapted from Dawar (1996) \\
\hline $\begin{array}{l}\text { 4. Non-Firm } \\
\text { Communication }\end{array}$ & $\begin{array}{l}\text { Adapted from Villarejo-Ramos and Sánchez-Franco } \\
\text { (2005); Bambauer-Sachse and Mangold (2011) }\end{array}$ \\
\hline 5. Security & $\begin{array}{l}\text { Adapted from Flavián, Torres, and Guinalíu } \\
\text { (2004) and Ming-Chi Lee (2008) }\end{array}$ \\
\hline 6. Corporate Image & $\begin{array}{l}\text { Adapted from Evans (1979); LeBlanc and } \\
\text { Nguyen (1996); O’Cass and Grace (2004) }\end{array}$ \\
\hline 7. Brand Attitude & $\begin{array}{l}\text { Adapted from Ruth and Simonin (2003); } \\
\text { Lafferty and Goldsmith (2005) }\end{array}$ \\
\hline 8. Intention to Use & $\begin{array}{l}\text { Adapted from O'Cass and Grace (2003); Lafferty } \\
\text { (2007) and Shukla (2010) }\end{array}$ \\
\hline
\end{tabular}

\section{RESULTS}

\section{Factor analysis}

The quantitative data collected in this study was analyzed by Statistical Process for Social Science (SPSS) software version 16 \& IBM AMOS Version 19. As the first step, we conducted principal components factor analysis with varimax rotation on the initial items, using a factor weight of 0.50 as the minimum cut-off value, discarding variables having values below it. Cronbach's alpha coefficient was used to test reliability; all items of the instrument at Likert scale have reliability of $96.3 \%$ which is considered satisfactory in this field (Nunnally \& Bernstein, 1994).

Empirical findings support the conceptual framework which extracted five independent constructs of the antecedents of corporate image of Islamic and conventional banks on the corporate brand image. The five key independent variables are found to have positive and significant effect on corporate image, as validated through factor analysis.

For the first construct that is corporate social responsibility, the value of Cronbach's alpha coefficient is 0.881 which is considered reliable enough to examine the construct. There were seven items in the initial questionnaire. In the Confirmatory Factor Analysis (CFA), four items are left which includes bank's charitable contributions to business activities, its ethical way of doing business, its support for good causes, and its environmental friendly policies and objectives. These items were found to be important to make the firm socially responsible. Literature and factor analysis also validates the importance of these items. This construct has Cronbach's alpha coefficient value of 0.881 .

Second construct is firm communication which consists of four items. These items are used to measure the impact of the firm's communication on corporate image, as well as on brand familiarity by getting information about the extent of advertising for the bank, whether people like advertising or not, whether these advertising campaigns are conducted frequently or not, and the advertising in comparison to competitor banks. These items were found to be important in deciding the level of firm communication inside the organization. Literature and the factor analysis also validates the importance of these items. This construct has Cronbach's alpha coefficient value of 0.803 .

Third construct consists of brand familiarity, which has five items. Literature suggests that these are the possible ways known about a brand to be familiar in public, including by getting information about the recognition level, purchase frequency, having the information, knowledge, and the level of experience about the bank. These items are found to be important in evaluating the familiarity for the specific bank. Literature and factor analysis also validates the importance of these items. This construct has Cronbach's alpha coefficient value of 0.845 .

Fourth construct is non-firm communication, which consists of four items. These items are used to measure the impact of nonfirm's communication on corporate image, as well as on brand familiarity by getting information about the media speaking highly for the bank or not, media speaking in comparison to its competitive banks, what family or acquaintances think about the bank, whether the customers consult those customers who have good experience with the bank or not, and lastly reading online reviews to know customers' impressions about the bank. These items are found to be important in deciding the role of non-firm communication for the bank's image. The literature and the factor analysis also validates the importance of these items. This construct has Cronbach's alpha coefficient value of 0.809 .

The fifth and final independent construct consists of security, which has three items. Literature suggests that the possible ways to know about the security of the bank service in transactions, deposits, and data are as follows: would customers feel safe and secure in providing personal privacy information to the bank or not, whether bank insures fraud or if hackers attack, would the customer feel a potential loss of status or not. Another aspect of security would be when customer starts using online banking and something goes wrong with online transactions, then would their family and friends think less of them or not. These items are found to be important in evaluating the security of the specific bank. Literature and factor analysis also validates the importance of these items. This construct has Cronbach's alpha coefficient value of 0.890 . CFA was also applied, and the above constructs extracted in exploratory factor analysis were confirmed with satisfactory parameters of the model. The results of CFA are depicted in fig. 2 and fig. 3. The items are more or less similar for conventional and Islamic banks with different loads. 
Figure 2. Confirmatory factor analysis for conventional banks

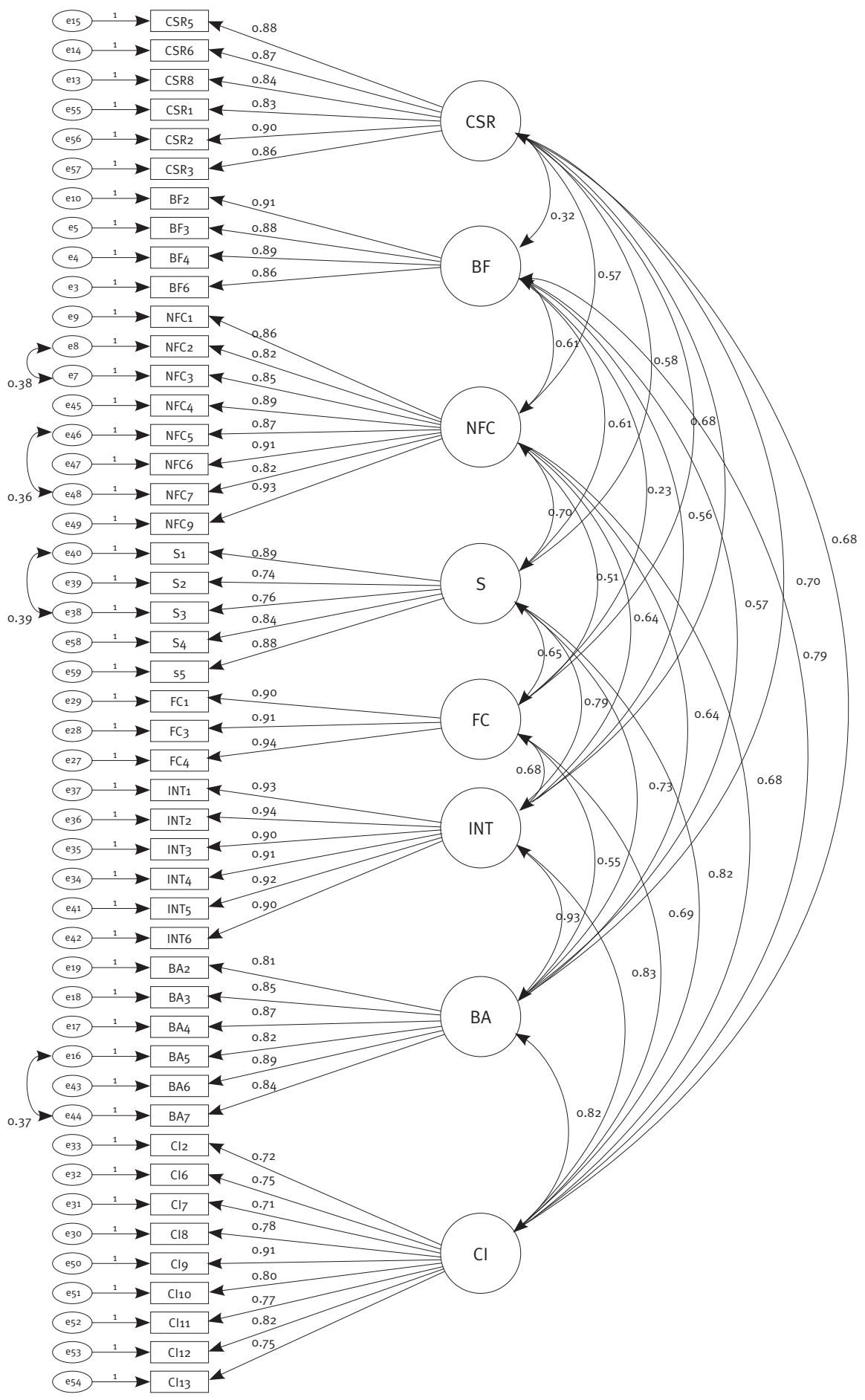


Figure 3. Confirmatory factor analysis for Islamic banks

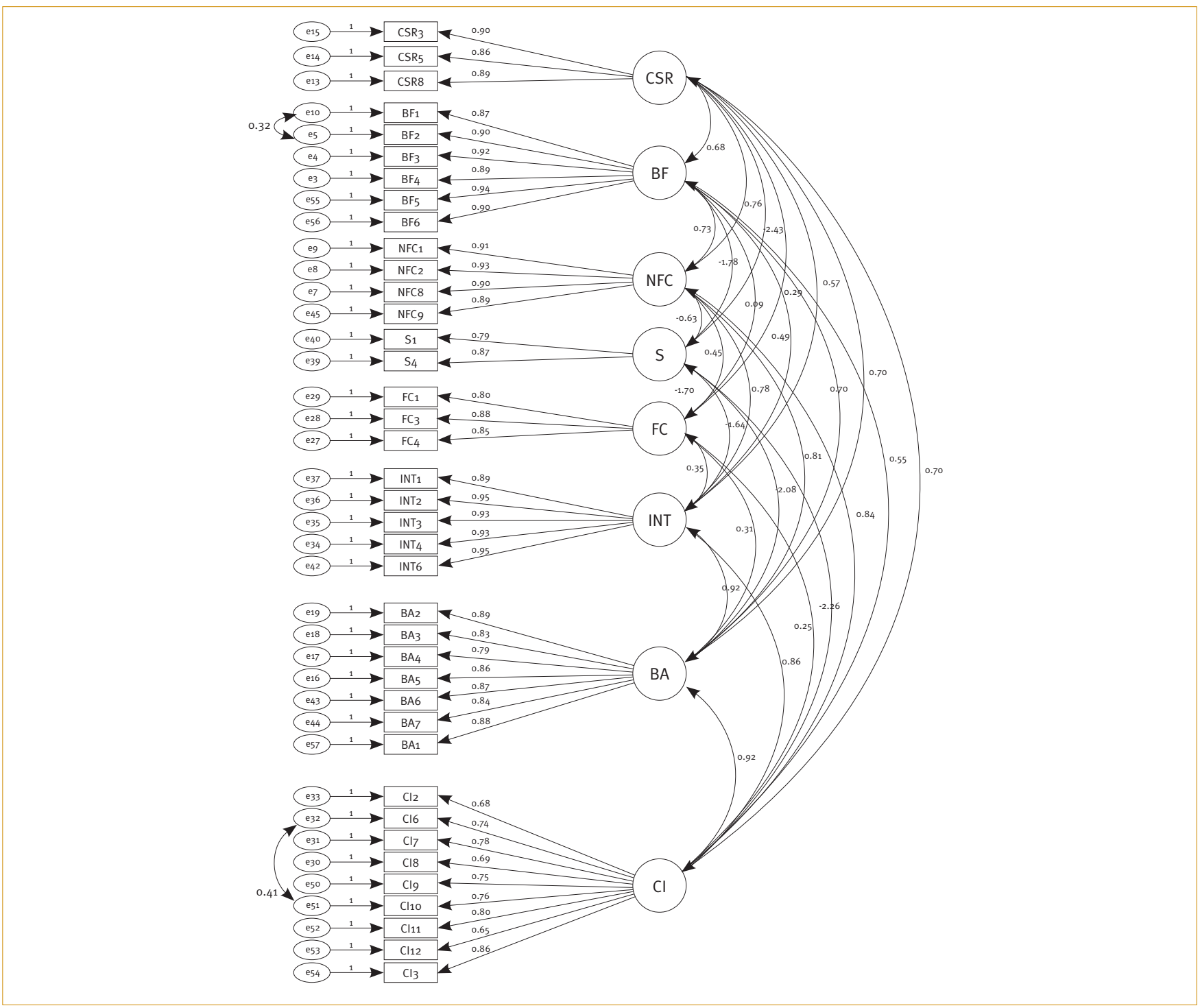

Notes: RMSEA=0,075, NFI=0,902, CFI=0,914, $\mid \mathrm{Fl}=0,917$

Figure 4. Estimates of consequences of corporate image (Conventional banks)

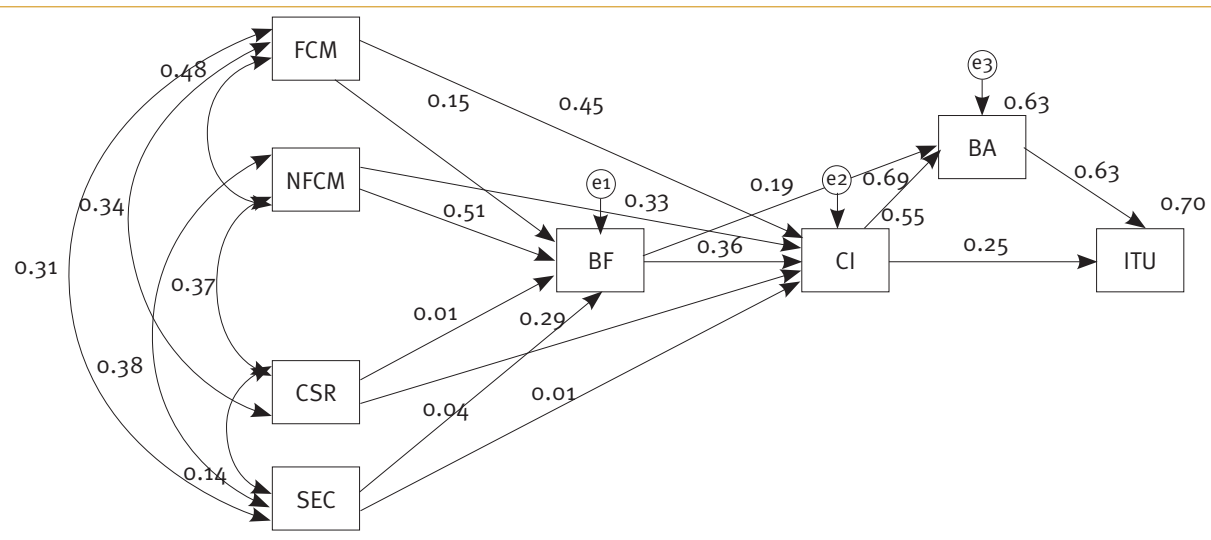


Figure 5. Estimates of Consequences of Corporate Image (Islamic Banks)

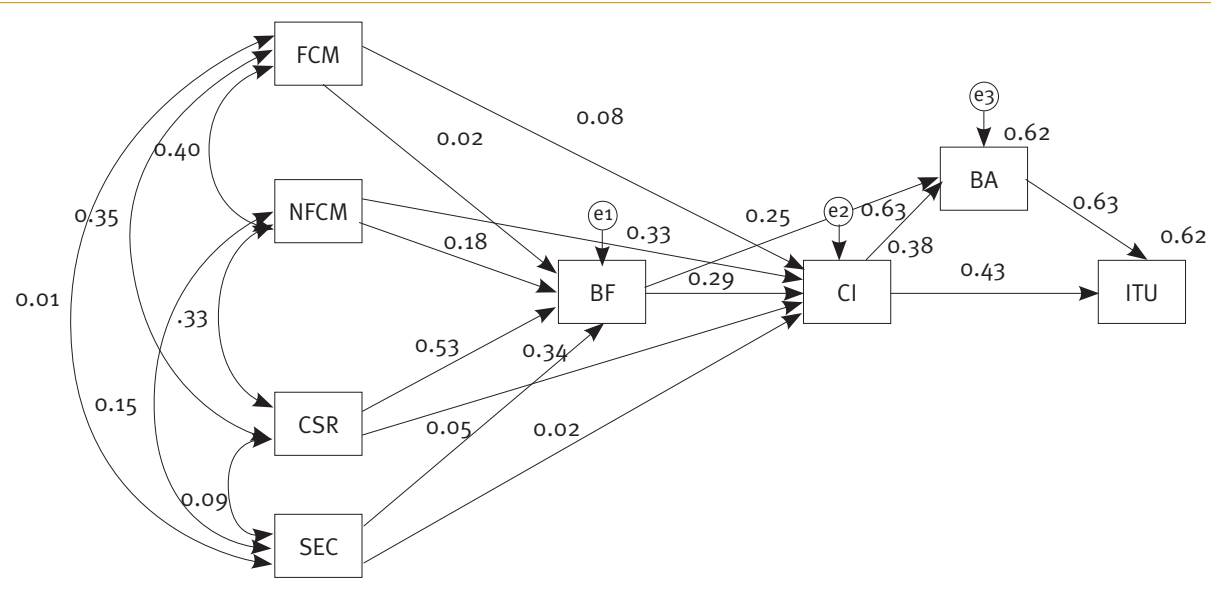

The results of validity tests are given in Table 1 . The results of $\lambda$ coefficients for all the observed variables of all dimensions used in this study were significant ( $\mathrm{t}>1.96)$ with standard loadings and $\mathrm{R}^{2}$ coefficients greater than 0.50 confirming the convergent validity. Moreover, all the constructs exceed the level of 0.60 for composite reliability and 0.50 level of variance extracted which prove the internal consistency of the scale. The criterion and discriminant validity were also satisfactorily shown by all the constructs.

\section{Table 1. Indices of measurement model}

\begin{tabular}{|c|c|c|c|c|}
\hline \multirow{2}{*}{ Constructs } & \multicolumn{2}{|c|}{ Conventional Banking } & \multicolumn{2}{|c|}{ Islamic Banking } \\
\hline & CR & Extracted Variance & CR & Extracted Variance \\
\hline 1. Corporate Social Responsibility (CSR) & 0.798 & 0.746 & 0.812 & 0.781 \\
\hline 3. Brand Familiarity (BF) & 0.816 & 0.782 & 0.911 & 0.815 \\
\hline 4. Non-Firm Communication (NFCM) & 0.823 & 0.755 & 0.921 & 0.823 \\
\hline 7. Intention to Use (INT) & 0.912 & 0.841 & 0.922 & 0.866 \\
\hline 8. Corporate Image $(\mathrm{Cl})$ & 0.93 & 0.61 & 0.91 & 0.55 \\
\hline
\end{tabular}

Table 2. Regression estimates of different dimensions of corporate image (Conventional banks)

\begin{tabular}{|c|c|c|c|c|c|c|c|c|}
\hline \multirow[b]{3}{*}{$\mathrm{Cl}$} & \multirow[b]{3}{*}{ ২-- } & \multirow{2}{*}{\multicolumn{2}{|c|}{ Relation }} & \multicolumn{2}{|c|}{ Direct } & \multicolumn{2}{|c|}{ Indirect } & \multirow{3}{*}{$\begin{array}{c}\text { Note } \\
\text { Supported }\end{array}$} \\
\hline & & & & \multirow{2}{*}{$\begin{array}{c}\text { Estimate } \\
0.364\end{array}$} & \multirow{2}{*}{$\begin{array}{c}\text { P-Value } \\
0.008\end{array}$} & \multirow[t]{2}{*}{ Estimate } & \multirow[t]{2}{*}{ P-Value } & \\
\hline & & $\mathrm{BF}$ & $\mathrm{H}_{1}$ & & & & & \\
\hline $\mathrm{BF}$ & $<--$ & FCM & $\mathrm{H}_{3}$ & 0.149 & 0.022 & & & Supported \\
\hline $\mathrm{Cl}$ & $<--$ & NFCM & $\mathrm{H}_{5}$ & -0.023 & 0.633 & 0.187 & 0.005 & Not supported \\
\hline $\mathrm{BF}$ & ২-- & CSR & $\mathrm{H}_{9}$ & 0.007 & 0.889 & & & Not supported \\
\hline $\mathrm{Cl}$ & $<--$ & SEC & $\mathrm{H}_{11}$ & 0.010 & 0.782 & 0.013 & 0.581 & Not supported \\
\hline $\mathrm{BF}$ & $\langle--$ & SEC & $\mathrm{H}_{12}$ & 0.036 & 0.599 & & & Not supported \\
\hline $\mathrm{BA}$ & $<--$ & $\mathrm{Cl}$ & $\mathrm{H} 14$ & 0.693 & 0.039 & & & Supported \\
\hline ITU & $<--$ & $\mathrm{Cl}$ & $\mathrm{H} 15$ & 0.246 & 0.009 & 0.436 & 0.012 & Supported \\
\hline
\end{tabular}


Table 3. Regression estimates for different dimensions of corporate image (Islamic banks)

\begin{tabular}{|c|c|c|c|c|c|c|c|c|}
\hline & & \multirow[b]{2}{*}{ Relation } & & \multicolumn{2}{|c|}{ Direct } & \multicolumn{2}{|c|}{ Indirect } & \multirow[b]{2}{*}{ Note } \\
\hline & & & & Estimate & P-Value & Estimate & P-Value & \\
\hline $\mathrm{Cl}$ & «-- & FCM & $\mathrm{H}_{2}$ & -0.077 & 0.293 & -0.006 & 0.746 & Not supported \\
\hline $\mathrm{BF}$ & $<--$ & FCM & $\mathrm{H}_{3}$ & -0.019 & 0.766 & & & Not supported \\
\hline $\mathrm{Cl}$ & $<--$ & CSR & $\mathrm{H} 8$ & 0.311 & 0.013 & 0.157 & 0.005 & Supported \\
\hline $\mathrm{BF}$ & $<--$ & CSR & $\mathrm{H}_{9}$ & 0.533 & 0.010 & & & Supported \\
\hline $\mathrm{Cl}$ & $<--$ & SEC & $\mathrm{H}_{11}$ & 0.017 & 0.759 & 0.017 & 0.372 & Not supported \\
\hline $\mathrm{BF}$ & $<--$ & SEC & $\mathrm{H}_{12}$ & 0.057 & 0.386 & & & Not supported \\
\hline
\end{tabular}

Goodness of fit test is provided at the bottom of fig 2 and fig 3 for conventional and Islamic banks respectively. The indices values for RMSEA, NFIA, CFI, IFI, and NNFI for both the banks have acceptable values (Hair, Anderson, Tatham, \& Black, 1998; Kline, 2005).

\section{Regression analysis}

In Structural Equation Modeling (SEM), linear regression helps to examine the relationship of independent variables with the dependent variables. Linear regression analysis is conducted to examine the relationship between all variables which are interdependent to analyze the significance of relationship between the variables. Significance level is 0.05 or below in regression analysis. The results of the regression analysis with SEM in IBM AMOS software are shown for conventional and Islamic banks below.

\section{Conventional banks}

The direct estimates and indirect estimates of various dimensions on other dimensions and their $p$-values for the conventional banks are given in Table 2 and Figure 4. The results will be discussed in the results and discussion section.

\section{Islamic banks}

The direct estimates and indirect estimates of various dimensions on other dimensions and their p-values for the Islamic banks are given in Table 3 and Figure. 5. The results will be discussed in the results and discussion section.

\section{Model Fit}

Structural equation modeling (SEM) is being used in this research to test the proposed conceptual framework. Goodness-of-fit test was conducted with different values. As a whole, the indicators lie in the acceptable range established by Hair et al. (1998) and Kline (2005) as shown in Table 4 below for both types of banks.

Table 4. Goodness of Fit Test

\begin{tabular}{l|c|c|c}
\hline $\begin{array}{l}\text { Fitness } \\
\text { index }\end{array}$ & $\begin{array}{c}\text { Required } \\
\text { value }\end{array}$ & $\begin{array}{c}\text { Conventional } \\
\text { results }\end{array}$ & $\begin{array}{l}\text { Islamic } \\
\text { results }\end{array}$ \\
\hline $\begin{array}{l}\text { Chi-Square } \\
\text { P-value }\end{array}$ & $>0.05$ & 0.046 & 0.055 \\
\hline CMIN/DF & $2.00-5.00$ & 2.404 & 5.087 \\
\hline GFI & $>0.90$ & 0.964 & 0.929 \\
\hline AGFI & $>0.90$ & 0.964 & 0.909 \\
\hline RMSEA & $<0.08$ & 0.084 & 0.075 \\
\hline RMR & $<0.08$ & 0.065 & 0.076 \\
\hline IFI & $>0.90$ & 0.979 & 0.917 \\
\hline NFI & $>0.90$ & 0.965 & 0.902 \\
\hline CFI & $>0.90$ & 0.979 & 0.914 \\
\hline NNFI/TLI & $>0.90$ & 0.936 & 0.918 \\
\hline
\end{tabular}




\section{DISCUSSION}

The results of regression analysis for conventional banks are listed in Table 2. The firm communication is significantly related to the corporate image $(p=0.019)$ and moderately related to brand familiarity $(p=0.022)$ whereas brand familiarity has significant effect on corporate image $(p=0.008)$. The indirect effect of firm communication is also significant. This result shows that brand familiarity plays the role of partial mediator between firm communication and corporate image. This result is in line with a prior study of Bravo et al. (2012). The security has no effect on corporate image and brand familiarity. CSR has significant effect on corporate image ( $p=0.012)$ but no effect on brand familiarity $(p=0.889)$; CSR has only direct effect on corporate image and brand familiarity has no role of mediator. The nonfirm communication has no effect on corporate image ( $p=0.633)$ whereas it affects brand familiarity $(p=0.013)$ and the indirect effect of non-firm communication through the mediator, brand familiarity, is significant. The corporate image very strongly affects the intention to use banking services. $(p=0.009)$ but moderately influences the brand attitude $(p=0.039)$. The brand attitude significantly affects the intention to use banking services $(p=0.009)$. This study reveals that non-firm communication and security does not have a direct effect on corporate image. However, the non-firm communication is positively related to brand familiarity and has an indirect effect on corporate image. Security has no indirect effect, even on corporate image, as it has no relationship with brand familiarity. The variable of security, which had been introduced to the model, has no role to play for building of brand familiarity or corporate image. Remaining variables, including brand familiarity, CSR, and firm communication are found important for directly affecting the corporate image, which in turn directly affects brand attitude and intention to use banking services.

The results of regression for Islamic banks are listed in Table 3. The firm communication is not related to corporate image $(p=0.293)$ and brand familiarity $(p=0.766)$. But brand familiarity has significant effect on corporate image $(p=0.009)$. Security has no effect on corporate image $(p=0.759)$ and brand familiarity $(p=0.386)$. CSR has significant effect on corporate image $(p=0.013)$ and on brand familiarity $(p=0.010)$ and the indirect effect of CSR through the mediator, brand familiarity, is also significant. This result shows that brand familiarity is playing a role of partial mediator between CSR and corporate image. These results of CSR positively influencing, directly or indirectly, corporate image support the earlier results of Ailawadi, Luan, Neslin, and Taylor (2011) and Lindgreen and
Swaen (2010) who said that if consumers see a company as socially responsible then their attitude towards company's products become positive and their intention for repeated purchase increases.

Non-firm communication has an effect on corporate image $(p=0.032)$ and it affects brand familiarity moderately $(p=0.048)$. The corporate image very strongly affects the intention to use banking services $(p=0.007)$ and brand attitude $(p=0.011)$. The brand attitude significantly affects the intention to use banking services. $(p=0.019)$.

As far as Islamic banks are concerned, our study found that firm communication is not in line with the prior study of Bravo et al. (2012). Security has no effect on brand familiarity and corporate image directly and also there is no indirect effect of this factor on corporate image. Conversely, brand familiarity and CSR highly affect corporate image. We also observed that corporate social responsibility has a significant effect on corporate image through brand familiarity. Non-firm communication is moderately related to brand familiarity, as well as corporate image. This factor also indirectly influences corporate image through brand familiarity. Corporate image had significant impact on brand attitude and intention to use the banking services. Brand attitude plays the role as the partial mediator between corporate image and intention to use banking services. Brand familiarity does have a positive relationship with corporate image as it is influenced by non-firm communication. Consumers in Pakistan are not conscious about the security issue of banking. Possible reasons could be that people do not heavily use online and internet banking facilities as yet in Pakistan. Also, the central bank has a very strong control over the banking industry and customers have a strong trust in this control.

It is, however, encouraging to see that corporate image creates positive brand attitude and more importantly intention for use of services of banks. Therefore, investment in the creation of positive non- firm communication is appreciated, based on the belief that Islamic banking is truly meeting the requirements of Shariah. This would result in creating strong intention to use banking services. Banking customers are also gaining awareness and are more conscious about the societal obligations of organizations, as we found that CSR does seem to build the corporate image.

As expected, the results of this study confirm the cognitive-affective-conative behavior model (Chiou et al., 2002) for the determinants of brand familiarity and corporate image, as well as corporate image, brand attitude, and intention to use services. 


\section{Managerial implications}

The study aimed to find out the antecedents and consequences of corporate image of banking sector in Pakistan, as well as to assess its mediating role and to make a comparison in two sectors of the banking industry: conventional and Islamic banks. With the help of a conceptual framework, this study demonstrates how efforts made towards better corporate image benefits banks in the form of better brand attitude and theory to use banking services. It also shows how the benefits of better bank image can be leveraged to increase outcome of banks in the form of success of banks (in terms of loyalty and development of brand attitude). The study reveals that better firm communication leads to better brand familiarity that ultimately results in a better corporate image in case of conventional banks. Investment in CSR activities directly builds the corporate image. Non-firm communication and CSR build the brand familiarity of Islamic banks. This ultimately enhances the corporate image of the Islamic banking industry in the country. The study shows that compared to other items, security does not make significant difference in improving the bank image, either of Islamic banks or conventional banks. In particular, customers seem to prefer Islamic banks over conventional banks based on brand familiarity of Islamic banks, the non-firm communication (word-of-mouth) and investment in CSR activities. On the other hand, the customers of conventional banks prefer their services are based on firm communication over the Islamic banks.

\section{Limitation and Future research}

This comparative study was aimed at consumers in Pakistan. It is necessary to check this model for different cultures and regions. We have extended the model of Bravo et al. (2012) with the additional two dimensions of corporate social responsibility and security. This model can further be extended to include other firm and non-firm communication sources, such as employees, publicity, and others.

\section{REFERENCES}

Abratt, R., \& Kleyn, N. (2012). Corporate identity, corporate branding and corporate reputations: Reconciliation and integration. European Journal of Marketing, 46(7-8), 1048-1063. doi:10.1108/03090561211230197

Ahmad, A., Rehman, K., Saif, I., \& Safwan, N. (2010). An empirical investigation of Islamic banking in Pakistan based on perception of service quality. African Journal of Business Management, 4(6), 1185-1193.
Ailawadi, K. L., Luan, Y. J., Neslin, S. A., \& Taylor, G. A. (2011). The impact of retailers' corporate social responsibility on price fairness perceptions and loyalty. Institut d'economie industrielle. Retrieved from http://idei.fr/doc/conf/inra/2011/ailawadi\%20kusum.pdf

Amin, M., Isa, Z., \& Fontaine, R. (2013). Islamic banks: Contrasting the drivers of customer satisfaction on image, trust and loyalty of Muslim and non-Muslim customers in Malaysia. International Journal of Bank Marketing, 31(2), 79-97. doi:10.1108/02652321311298627

Balmer, J.M.T., \& Greyser, S.A. (2003). Revealing the corporation: Perspectives on identity, image, reputation, corporate branding, and corporate-level marketing. London, UK: Routledge.

Balmer, J. M. T., \& Greyser, S. A. (2006). Corporate marketing: Integrating corporate identity, corporate branding, corporate communications, corporate image and corporate reputation. European Journal of Marketing, 40(7-8), 730-741. doi:10.1108/03090560610669964

Bambauer-Sachse, S., \& Mangold, S. (2011). Brand equity dilution through negative online word-of-mouth communication. Journal of Retailing and Consumer Services, 18(1), 38-45. doi:10.1016/j.jretconser.2010.09.003

Bravo, R., Montaner, T., \& Pina, J. M. (2012). Corporate brand image offinancial institutions: A consumer approach. Journal of Product and Brand Management, 21(4), 232- 245. doi:10.1108/10610421211246649

Bryman, A., \& Bell, E. (2015). Business research methods. New York, NY: Oxford University Press.

Carbone, L. P., \& Haeckel, S. H. (1994). Engineering customer experiences. Marketing Management, 3(3), 8-18.

Castelo, M., \& Lima, L. (2006). Communication of corporate social responsibility by Portuguese banks: A legitimacy theory perspective. Corporate Communications, 11(3), 232-248. doi:10.1108/13563280610680821

Chang, H. H., \& Liu, Y. M. (2009). The impact of brand equity on brand preference and purchase intentions in the service in dustries. The Service Industries Journal, 29(12), 1687-1706. doi:10.1080/02642060902793557

Chiou, J. S., Droge, C., \& Hanvanich, S. (2002). Does customer knowledge affect how loyalty is formed?. Journal of Service Research, 5(2), 113-124. doi:10.1177/109467002237494

Cornelissen, J. P., \& Elving, W. J. L. (2003). Managing corporate identity: An integrative framework of dimensions and determinants. Corporate Communications: An International Journal, 8(2), 114-120. doi:10.1108/1356328031047553

Crane F. G. (1990). The need for corporate advertising in the financial services industry: A case study illustration. Journal of Services Marketing, 4(2), 31-37. doi:10.1108/EUMoooo000002509

Darus, F., Fauzi, H., Purwanto, Y., Yusoff, H., Amran, A., Zain, M. M., ... and Nejati, M. (2014). Social responsibility reporting of Islamic banks: Evidence from Indonesia. International Journal of Business Governance and Ethics, 9(4), 356-380. doi:10.1504/IJBGE.2014.066275

Dawar, N. (1996). Extensions of broad brands: The role of retrieval in evaluations of fit. Journal of Consumer Psychology, 5(2), 189-207. doi:10.1207/S15327663jcp0502_05

de Leaniz, P. M. G., \& del Bosque Rodríguez, I. R. (2016). Corporate image and reputation as drivers of customer loyalty. Corporate Reputation Review, 19(2), 166-178. doi:10.1057/crr.2016.2 
Dichter, E. (1985). What's in an image? Journal of Consumer Marketing, 2(1), 75-81. doi:10.1108/ebo38824

Dusuki A. W \& Abdullah N., (2007). Why do Malaysian customers patronize Islamic Banks? International Journal of Bank Marketing, 25(3), 142-16o. doi:10.1108/02652320710739850

Dutton, J. E., Dukerich, J. M., \& Harquail, C. V. (1994). Organizational images and member identification. Administrative Science Quarterly, 39(2), 239-263. doi:10.2307/2393235

Erol, C., Kaynak, E., \& El-Bdour, R. (1990). Conventional and Islamic bank: Patronage behaviour of Jordanian customers. International Journal of Bank Marketing, 8(4), 25-35. doi:10.1108/02652329010004231

Evans, R. (1979). Bank selection: It all depends on the situation. Journal of Bank Research, 9(Winter), 242-245.

Faircloth, J. B., Capella, L. M., \& Alford, B. L. (2001). The effect of brand attitude and brand image on brand equity. Journal of Marketing Theory and Practice, 9(3), 61-75.

Flavián, C., Torres, E., \& Guinalíu, M. (2004). Corporate image measurement: A further problem for the tangibilization of Internet banking services. International Journal of Bank Marketing, 22(5), 366-384. doi:10.1108/02652320410549665

Gounaris S., \& Stathakopoulos, V. (2004). Antecedents and consequences of brand loyalty: An empirical study. Journal of Brand Management, 11(4), 283-306. doi:10.1057/palgrave.bm.2540174

Gounaris, S., Stathakopoulos, V., \& Athanassopoulos, A. (2003). Antecedents to perceived service quality: An exploratory study in the banking industry. International Journal of Bank Marketing, 21(4), 168-19o. doi:10.1108/02652320310479178

Gray, E. R., \& Balmer, J. M. (1998). Managing corporate image and corporate reputation. Long Range Planning, 31(5), 695-702. doi:10.1016/ So024-6301(98)00074-0

Hair, J. F. Jr., Anderson, R. E., Tatham, R. L., \& Black, W. C. (1998). Multivariate Data Analysis, (5 th Edition). Upper Saddle River, NJ: Prentice Hall.

Haniffa, R., \& Hudaib, M. (2007). Exploring the ethical identity of Islamic banks via communication in annual reports. Journal of Business Ethics,76(1), 97-116. doi:10.1007/s10551-006-9272-5

Haron, S., Ahmad, N., \& Planisek, S. L. (1994). Bank patronage factors of Muslim and non-Muslim customers. International Journal of Bank Marketing, 12(1), 32-40. doi:10.1108/02652329410049599

Hart, A. E., \& Rosenberger, P. J. (2004). The effect of corporate image in the formation of customer loyalty: An Australian replication. Australian Marketing Journal, 12(3), 88-96. doi:10.1016/S14413582(04)70109-3

Hsiong-Ming, L., Ching-Chi, L., \& Cou-Chen, W. (2011). Brand image strategy affects brand equity after M \& A. European Journal of Marketing, 45(7-8), 1091-111. doi:10.1108/03090561111137624

Hussain, I. A., Ishak, N. A., Daud, N., \& Yunus, N. (2014). Impact of organizational image in determining the level of engagement among commercial banks' employees. In Proceedings of the 1st AAGBS International Conference on Business Management 2014 (pp. 117-126). Singapore: Springer.

Iqbal, M. \& Molyneux, P. (2005). Thirty years of Islamic banking: History, performance and prospects. New York, NY: Palgrave Macmillan.
Islamic Banking Bulletin. (2016). Islamic Banking Department, State Bank of Pakistan. Retrieved from https://ceif.iba.edu.pk/pdf/islam. ic-banking-bulletin-december2016.pdf

Johnson, M., \& Zinkhan, G. M. (1990). Defining and measuring company image. In Proceedings of the 1990 Academy of Marketing Science Annual Conference (pp. 346-350). Cham, Switzerland: Springer International Publishing.

Kaurav, R. P. S., Paul, J., \& Chowdhary, N. (2015). Effect of internal marketing on hotels: Empirical evidence for internal customers. International Journal of Hospitality \& Tourism Administration, 16(4), 311-330. doi:10.1080/15256480.2015.1090247

Khattak, N. A., \& Rehman, K. (2010). Customer satisfaction and awareness of Islamic banking system in Pakistan. African Journal of Business Management, 4(5), 662-671.

Kim, K. (2006). Managing corporate brand image through sports sponsorship: Impacts of sponsorship on building consumer perceptions of corporate ability and social responsibility. Doctoral thesis, University of Texas, Austin, TX.

Kline, R. B. (2005). Principles and practice of structural equation modeling (2nd ed.). New York, NY: Guilford Press.

Lafferty, B. A. (2007). The relevance of fit in a cause-brand alliance when consumers evaluate corporate credibility. Journal of Business Research, 60(5), 447-453. doi:10.1016/j.jbusres.2006.09.030

Lafferty, B. A., \& Goldsmith, R. E. (2005). Cause-brand alliances: Does the cause help the brand or does the brand help the cause? Journal of Business Research, 58(4), 423-429. doi:10.1016/j.jbusres.2003.07.001

LeBlanc, G., \& Nguyen, N. (1996). Cues used by customers evaluating corporate image in service firms: An empirical study in financial institutions. International Journal of Service Industry Management, 7(2), 44-56. doi:10.1108/09564239610113460

Lichtenstein, D. R., Drumwright, M. E., \& Braig, B. M. (2004). The effect of corporate social responsibility on customer donations to corporate-supported nonprofits. Journal of Marketing, 68(4), 16-32.

Lindgreen, A., \& Swaen, V. (2010). Corporate social responsibility. International Journal of Management Reviews, 12(1), 1-7. doi:10.1111/ j.1468-2370.2009.00277.x

Maali, B., Casson, P., \& Napier, C. (2006). Social reporting by Islamic banks. Abacus, 42(2), 266-289. doi:10.1111/j.14676281.2006.00200.x

Memon, N. A. (2007). Islamic banking: Present and future challenges. Journal of Management and Social Sciences, 3(1), 1-10.

Metawa, S. A., \& Almossawi, M. (1998). Banking behavior of Islamic bank customers: Perspectives and implications. International Journal of Bank Marketing, 16(7), 299-313. doi:10.1108/02652329810246028

Mokhtar, H. S. A., Abdullah, N., \& Alhabshi, S. M. (2008). Efficiency and competition of Islamic banking in Malaysia. Humanomics, $24(1), 28$ 48. doi:10.1108/08288660810851450

Nunnally, J. C., \& Bernstein, I. H. (1994). Psychometric theory (3 rd ed.). New York, NY: McGraw-Hill.

Obaid, A. (2013). Changes in the pay structures and systems in the banking sector of Pakistan: Implications for a differentiated workforce and the employee psychological contract. Doctoral thesis. The University of Manchester. 
O’Cass, A., \& Grace D. (2003). An exploratory perspective of service brand associations. Journal of Services Marketing, 17(5), 452-475. doi:10.1108/08876040310486267

O’Cass, A., \& Grace, D. (2004). Exploring consumer experiences with a service brand. Journal of Product \& Brand Management, 13(4), 257268. doi:10.1108/10610420410546961

Osman, I., Alwi, S. F. S., Mokhtar, I., Ali, H., Setapa, F., Muda, R., \& Rahim, A. R. A. (2015). Integrating institutional theory in determining corporate image of Islamic banks. Procedia-Social and Behavioral Sciences, 211(Nov), 560-567. doi:10.1016/j.sbspro.2015.11.074

Raza, S. A., \& Hanif, N. (2013). Factors affecting internet banking adoption among internal and external customers: A case of Pakistan. International Journal of Electronic Finance, 7(1), 82-96. doi:10.1504/ IJEF.2013.051746

Richardson, B. A., \& Robinson, C. G. (1986). The impact of internal marketing on consumer service in a retail bank. International Journal of Bank Marketing , 4(5), 3-30. doi:10.1108/eb010791

Ruth, J., \& Simonin, B. (2003). "Brought to you by brand A and brand B": Investigating multiple sponsors' influence on consumers' attitudes toward sponsored events. Journal of Advertising, 32(3), 19-30.

Saunders, M., Lewis, P., \& Thornhill, A. (2015). Research methods for business students. Essex, UK: Pearson Education Limited.

Shee, P. S. B., \& Abratt, R. (1989). A new approach to the corporate image management process. Journal of marketing management, 5(1), 63-76. doi:10.1080/0267257X.1989.9964088

Shukla, A., Sharma, N. K., \& Swami, S. (2010). Website characteristics, user characteristics and purchase intention: Mediating role of website satisfaction. International Journal of Internet Marketing and Advertising, 6(2), 142-167. doi:10.1504/IJIMA.2010.032479

Siddiqui, M. N. (2004). Riba, bank interest and the rationale of its prohibition. Jeddah: Islamic Research and Training Institute.

Souiden, N., Kassin, N. M., \& Hong, H.J. (2006). The effect of corporate branding dimensions on consumers' product evaluation. A cross-cultural analysis. European Journal of Marketing, 40(7-8), 825-845. doi:10.1108/03090560610670016
State Bank of Pakistan. (2014). Strategic plan: Islamic banking industry of Pakistan 2014-2018. Islamic banking department of State Bank of Pakistan. Retrieved from http://www.sbp.org.pk/departments/pdf/ StrategicPlanPDF/Strategy\%2oPaper-Final.pdf

Usmani, M. T. (1998). An Introduction to Islamic Finance. Karachi: Idaratul Ma'arif.

Van Riel, C. B. M. (1997). Research in corporate communication: An overview of an emerging field. Management Communication Quarterly, 11(2), 288-309. doi:10.1177/0893318997112005

Van Riel, A., Lemmink, J., \& Ouwersloot, H. (2001). Consumer evaluations of service brand extensions. Journal of Service Research, 3(3), 220-231. doi:10.1177/109467050133003

Villarejo-Ramos, A. F., \& Sánchez-Franco, M. J. (2005). The impact of marketing communication and price promotion on brand equity. Journal of Brand Management, 12(6), 431-444. doi:10.1057/palgrave.bm. 2540238

Whetten, D. A. Lewis, D., \& Mischel, L. J. (1992). Towards an integrated model of organizational identity and member commitment. Paper presented at the Annual Meeting of the Academy of Marketing, Las Vegas, NV.

Wilson, R. (2006). Islam and business. Thunderbird International Business Review, 48(1), 109-123. doi:10.1002/tie.20088

Worcester, R. (2009). Reflections on corporate reputations. Management Decision, 47(4), 573-589. doi:10.1108/00251740910959422

World Islamic Banking Competitiveness Report. (2016). New realities New opportunities. EY Building a better working world. Retrieved from http:// www.ey.com/Publication/vwLUAssets/Corporate_brochure_2017/\$FILE/Corporate_Cyprus $+5 \mathrm{~mm}$ _bleeds_final_low_resc.pdf

Yeo, R. K., \& Youssef, M. A. (2010). Communicating corporate image into existence: The case of the Saudi banking industry. Corporate Communications: An International Journal, 15(3), 263-280. doi:10.1108/13563281011068122 